\title{
Neuroendocrine carcinoma of the gall bladder in a young lady presenting with upper abdominal heaviness: a common complaint and a rare diagnosis
}

\author{
Deep Chakrabarti, 1 Sumaira Qayoom, ${ }^{2}$ Arunima Ghosh, ${ }^{1}$ Rajeev Gupta ${ }^{1}$
}

${ }^{1}$ Department of Radiotherapy, King George's Medical University, Lucknow, Uttar Pradesh, India

${ }^{2}$ Department of Pathology, King George's Medical University, Lucknow, Uttar Pradesh, India

\section{Correspondence to}

Dr Deep Chakrabarti, deepchakrabarti.19@gmail.com

Accepted 21 March 2019

\section{DESCRIPTION}

A 34-year-old woman was referred from internal medicine with complaints of occasional upper abdominal heaviness and pain for 4 months. Her WHO performance score was 1 . On examination, she was icteric and had multiple, brownish nodular skin lesions on limbs and back that were soft to firm in consistency. On per abdominal examination, the liver span was approximately $5 \mathrm{~cm}$ below the right subcostal margin at midclavicular line. She underwent CT scan of the abdomen, which revealed an ill-defined heterogeneously enhancing lesion in the gall bladder fossa infiltrating adjacent liver parenchyma, duodenum and the common bile duct at the porta hepatis (figure $1 \mathrm{~A}-\mathrm{L}$ ). Her biopsy revealed liver parenchyma infiltrated by tumour cells with hyperchromatic nucleus, fine chromatin, inconspicuous nucleoli and scant cytoplasm (figure 2A,B). Tumour cells were positive for synaptophysin and showed high MIB1 labelling index (figure 2C,D). A diagnosis of neuroendocrine carcinoma of gall bladder was made. She was discussed in tumour board and was offered palliative chemotherapy.

Primary neuroendocrine tumours (NETs) of the gall bladder (GB) are rare entities, and they represent only about $0.5 \%$ of all NETs. ${ }^{1}$ They have a variable age of presentation and a slight female preponderance of about $2: 1 .^{2}$ It was initially believed that they arise by migration from the neural crest cells, but now it is accepted that they arise from pluripotent stem cells in the gastrointestinal system. ${ }^{3}$ GB-NETs

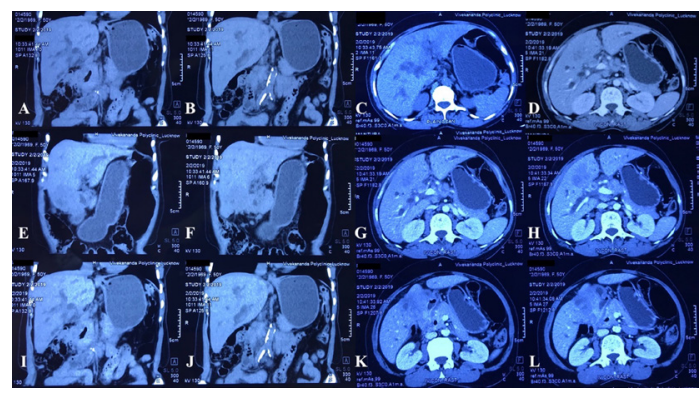

Limited 2019. No commercial re-use. See rights and permissions. Published by BMJ.

To cite: Chakrabarti $D$, Qayoom S, Ghosh A, et al. BMJ Case Rep 2019;12:e229684. doi:10.1136/bcr-2019229684

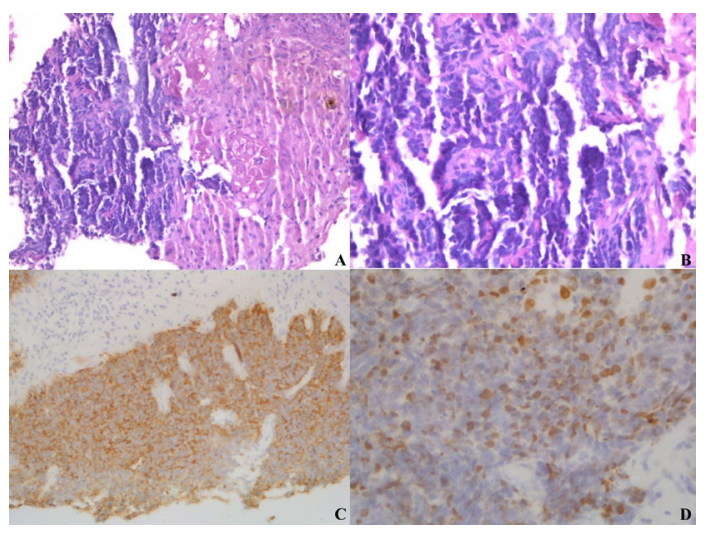

Figure 2 Section shows liver biopsy infiltrated by tumour cells (A) (H\&E 200x). Higher power shows tumour cells with hyperchromatic nuclei, fine chromatin, inconspicuous nucleoli and scant cytoplasm (B) (H\&E $630 \times)$. Tumour cells are positive for synaptophysin (C) (200x). Tumour cells show high MIB1 labelling index (D) $(200 x)$.

may arise from endocrine cells appearing in the neck, body and fundus of the gall bladder, induced by gastric or intestinal metaplasia. ${ }^{45}$ They can be associated with neurofibromatosis type 1 (NF-1), which is one of the most common hereditary cancer syndromes and has an autosomal dominant inheritance pattern. When associated with NF-1, cutaneous lesions much precede the gastrointestinal manifestations, and there is a general paucity of symptoms. ${ }^{6}$ Symptoms tend to be non-specific and compose of upper abdominal discomfort or pain, jaundice and weight loss. The development of a carcinoid syndrome is rare. Cholelithiasis may be an associated finding. ${ }^{5}$ As per WHO, GB-NETs are classified as grade 1 NET, grade 2

\section{Learning points}

- Neuroendocrine tumours of the gall bladder are rare, aggressive tumours that present with nonspecific symptoms.

- Gall bladder neuroendocrine tumours may be associated with an underlying hereditary tumour syndrome, and there is a need to screen for gastrointestinal malignancies in such patients.

- Overall survival is poor even with multimodality treatment. 
NET, neuroendocrine carcinoma (large cell or small cell type) and mixed adenoneuroendocrine carcinoma. ${ }^{7}$ They express neuroendocrine markers on immunohistochemistry. ${ }^{7}$ GB-NETs have an aggressive clinical course and are often unresectable at the time of diagnosis. En bloc surgical resection forms the best chance for cure in early lesions, but patients develop recurrent or metastatic disease even after complete surgical resection. ${ }^{8}$ Most cases are managed by palliative chemoradiotherapy. Data from the Surveillance, Epidemiology and End Results Program database report a median survival of only about 10 months, with a 5 -year survival rate of $36.9 \%$ in carcinoids and $0 \%$ in small cell carcinoma. 5

\section{Twitter deep 190690}

Contributors DC: concept, design, manuscript writing and image acquisition. SQ: supervision, histopathological work-up, image acquisition and critical analyses. AG: concept, design and image acquisition. RG : supervision and critical analyses. All authors read and approved the final draft.

Funding The authors have not declared a specific grant for this research from any funding agency in the public, commercial or not-for-profit sectors.

Competing interests None declared.

Patient consent for publication Obtained.
Provenance and peer review Not commissioned; externally peer reviewed.

\section{REFERENCES}

1 Yao JC, Hassan M, Phan A, et al. One hundred years after "carcinoid": epidemiology of and prognostic factors for neuroendocrine tumors in 35,825 cases in the United States. J Clin Oncol 2008;26:3063-72.

2 Deehan DJ, Heys SD, Kernohan N, et al. Carcinoid tumour of the gall bladder: two case reports and a review of published works. Gut 1993;34:1274-6.

3 Pearse AG. The cytochemistry and ultrastructure of polypeptide hormone-producing cells of the APUD series and the embryologic, physiologic and pathologic implications of the concept. J Histochem Cytochem 1969;17:303-13.

4 Laitio M. Goblet cells, enterochromaffin cells, superficial gastric-type epithelium and antral-type glands in the gallbladder. Beitr Pathol 1975;156:343-58.

5 Eltawil KM, Gustafsson BI, Kidd M, et al. Neuroendocrine tumors of the gallbladder: an evaluation and reassessment of management strategy. J Clin Gastroenterol 2010;44:687-95.

6 Agaimy A, Vassos N, Croner RS. Gastrointestinal manifestations of neurofibromatosis type 1 (Recklinghausen's disease): clinicopathological spectrum with pathogenetic considerations. Int J Clin Exp Pathol 2012;5:852-62.

7 Komminoth P, Arnold R, Capella C. Neuroendocrine neoplasms of the gallbladder and extrahepatic bile ducts. In: Bosman FT, Carneiro F, Hruban RH, Theise ND, et al. eds. World health organization of tumours: pathology and genetics of tumours of the digestive system. 4th edn. Lyon (France): International Agency for Research on Cancer (IARC), 2010:274-6.

8 Duffy A, Capanu M, Abou-Alfa GK, et al. Gallbladder cancer (GBC): 10-year experience at Memorial Sloan-Kettering Cancer Centre (MSKCC). J Surg Oncol 2008;98:485-9.

Copyright 2019 BMJ Publishing Group. All rights reserved. For permission to reuse any of this content visit

https://www.bmj.com/company/products-services/rights-and-licensing/permissions/

BMJ Case Report Fellows may re-use this article for personal use and teaching without any further permission.

Become a Fellow of BMJ Case Reports today and you can:

- Submit as many cases as you like

- Enjoy fast sympathetic peer review and rapid publication of accepted articles

- Access all the published articles

Re-use any of the published material for personal use and teaching without further permission

For information on Institutional Fellowships contact consortiasales@bmjgroup.com

Visit casereports.bmj.com for more articles like this and to become a Fellow 